\title{
Production and manufacturing of biosimilar insulins: implications for patients, physicians, and health care systems
}

This article was published in the following Dove Press journal:

Biosimilars

10 November 2014

Number of times this article has been viewed

\author{
Martin K Kuhlmann' \\ Andrea Schmidt ${ }^{2}$ \\ 'Department of Internal \\ Medicine-Nephrology, Klinikum \\ im Friedrichshain, Berlin, Germany; \\ ${ }^{2}$ Sanofi, Frankfurt, Germany
}

\begin{abstract}
More than 380 million people worldwide have diabetes, a disease that accounts for almost US $\$ 550$ billion in global health care spending. The majority of patients with diabetes will require insulin replacement as part of their therapeutic regimen. In some countries, the approaching patent expiry dates for the long-acting insulin analog insulin glargine mean there is increasing interest in the potential of biosimilar insulins. However, the production and manufacturing of biosimilar insulins is a proprietary, complex, multistep process in which each stage can potentially introduce variability, possibly leading to adverse clinical and safety outcomes. Thus, marketing authorization in countries in which stringent regulatory requirements are in place requires manufacturers to demonstrate similarity in pharmacokinetic/pharmacodynamic properties, clinical efficacy, and adverse event and immunogenicity profiles, as well as provide proof of the quality of the production process between the biosimilar and the reference insulin product. A risk management plan and pharmacovigilance program may also be needed for the approval process. Regulatory guidelines for the introduction of biosimilar insulins differ between countries but are most developed for the European Union. As of the date of submission of this manuscript (April 30, 2014), no insulin or insulin analogs have received marketing authorization based on the European Union standards established for biosimilars; however, European Medicines Agency approval of a biosimilar glargine insulin is awaited for the end of 2014. In recent years several copies of the long-acting insulin glargine have been brought onto the market in countries such as India, the People's Republic of China, Pakistan, Mexico, and Kenya without following a biosimilar pathway. In this article, we review the key issues associated with the production and manufacturing of biosimilar insulins, including a European regulatory perspective on manufacturing guidelines designed to ensure clinical efficacy and patient safety.
\end{abstract}

Keywords: biosimilar insulin, follow-on insulin, regulatory guidelines, diabetes

\section{Introduction}

In 2013, the International Diabetes Federation estimated that 382 million people worldwide had diabetes and that this disease accounted for more than US\$548 billion in global health care expenditures. ${ }^{1}$ Type 2 diabetes mellitus is by far the most common form of diabetes, accounting for $90 \%-95 \%$ of diagnosed cases in adults. ${ }^{2}$ Because type 2 diabetes mellitus is a progressive disease, the majority of patients eventually require insulin replacement as part of their therapeutic regimen. ${ }^{3,4}$ Insulin replacement therapy can be provided by five main types of insulin: short-acting regular insulin, intermediateacting neutral protamine Hagedorn insulin, rapid-acting insulin analogs (eg, insulin lispro, insulin aspart, and insulin glulisine), long-acting basal insulin analogs (eg, insulin glargine, insulin detemir, and insulin degludec), or premixed insulin. Insulin analogs provide a more physiologic insulin profile and reduce the pharmacokinetic
Correspondence: Martin K Kuhlmann Vivantes Klinikum im Friedrichshain, Landsberger Allee 49, 10249 Berlin, Germany

Tel $+4930 \quad 13023 \quad 1322$

Fax +4930 I3023 2046

Email martin.kuhlmann@vivantes.de submit your manuscript | www.dovepress.com

Dovepress

http://dx.doi.org//0.2147/BS.S36043 
and pharmacodynamic (PK/PD) variability associated with regular and neutral protamine Hagedorn insulins..$^{5-11}$

Human insulin is a complex molecule with precise primary, secondary, and tertiary structures that are essential for biological activity (Figure 1). ${ }^{12}$ It is a nonglycosylated, disulfide-bonded heterodimer of 51 amino acids in two chains (Figure 2A), which, on top of the pancreatic baseline insulin production, is rapidly released from islet cells in response to a meal. The biologic-kinetic effects of endogenously secreted insulin are not completely matched by recombinant human insulin when applied subcutaneously. Therefore, alterations in the amino acid sequence of natural insulin have been introduced, which mainly allow for either an increased (long-acting insulin analogs glargine, detemir, and degludec) or shortened (rapidacting insulin analogs lispro, aspart, and glulisine) duration of action. Insulin glargine has two arginine residues added to the $\mathrm{C}$ terminus of the $\mathrm{B}$ chain and a glycine replacing the asparagine at A21 (Figure 2B), ${ }^{13}$ whereas insulin detemir has a myristic acid molecule covalently bound to the lysine at B29 (Figure 2C). ${ }^{14}$ In insulin lispro, the positions of B28 proline and B29 lysine are swapped (Figure 2D), and insulin aspart contains an aspartic acid at B28 instead of proline (Figure 2E). ${ }^{15}$ In insulin glulisine, the amino acid asparagine at position B3 is replaced by lysine, and the lysine in position B29 is replaced by glutamic acid (Figure 2F). In insulin degludec, the threonine at position B30 is deleted and a 16-carbon fatty diacid is added, attached to lysine at position B29 via a glutamic acid spacer (Figure $2 \mathrm{G}){ }^{16}$

It is well recognized that long-acting insulin analogs are associated with less nocturnal hypoglycemia, and possibly slightly less weight gain, than neutral protamine Hagedorn

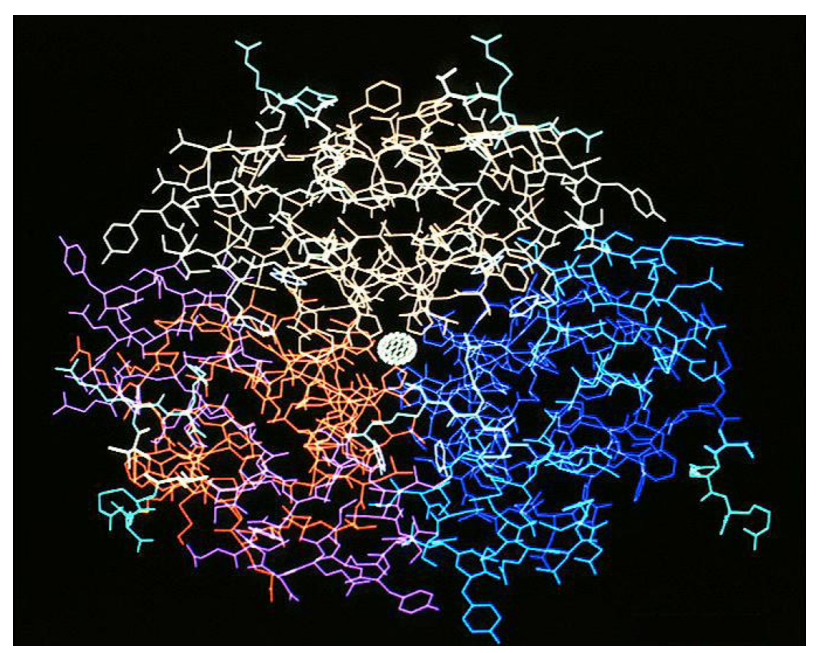

Figure I Insulin molecule (hexamer).

Notes: Copyright (C) 20I4 Hilgenfeld R, Seipke G, Berchtold H, Owens DR. Reproduced from Hilgenfeld R, Seipke G, Berchtold H, Owens DR. The evolution of insulin glargine and its continuing contribution to diabetes care. Drugs. 2014 Jun;74(8):91 I-927. ${ }^{2}$ insulin, but at a higher cost, ${ }^{4}$ which contributes significantly to global insulin sales, which reached $\$ 16.7$ billion in $2011 .^{17}$ Insulins manufactured using recombinant DNA technology are proteins and are therefore "biological" drugs. Once the patent on a drug expires, other manufacturers are at liberty to make "copies" of that biological drug. Although copies of chemically synthesized medicines can be assumed to be identical with regard to structure and effects with the original authorized medicine, "copies" of biologicals are never identical to the original drug and, as such, can only reach a certain degree of similarity. To point out these important differences to generic copies, officially approved copies of already-authorized biotherapeutics are termed "biosimilars," not "generics." The term "biosimilar" (also called a "follow-on" biological in the United States and a "subsequent entry" biological in Canada) should therefore only be used for those copies of biotherapeutics that have been approved by authorities after they have undergone a stringent approval process specifically designed for biosimilars, as is the case in Europe.

Copies of the long-acting insulin glargine have been brought onto the market in countries where, at the time of approval, regulations for biological medicinal products were less stringent, such as India, the People's Republic of China, Pakistan, Mexico, and Kenya (Table 1). In most of these countries, these copy-insulins were registered with no strict requirement to demonstrate similarity to the reference product, Lantus $^{\circledR}$ (Sanofi, Paris, France). As the patent expiry dates of the long-acting insulin analogs are approaching in some countries, there is increasing interest in the potential of basal or long-acting biosimilar insulins. Biosimilar insulins have the potential to reduce treatment costs, and therefore improve access for patients, physicians, and health care systems. ${ }^{17,18}$

Among long-acting insulin analogs not only insulin glargine but also insulin detemir is a potential target for biosimilar development. However, at this time, there are no data available pointing toward the development of a biosimilar insulin detemir or to the availability of other copies of insulin detemir on any market. In contrast, publicly available information indicates activities connected with the development of copies or biosimilar versions of short-acting insulin analogs, such as insulin lispro and insulin aspart. ${ }^{19,20}$

The requirement for regulatory approval of biosimilars varies globally, with detailed regulations specific to biosimilar insulins in the European Union (EU), Australia, Canada, and Chile and general biosimilar regulations in the United States and some emerging markets (eg, South Korea and India, based on guidelines from the World Health Organization $^{21}$ ); however, in the People's Republic of China, 


\section{A}

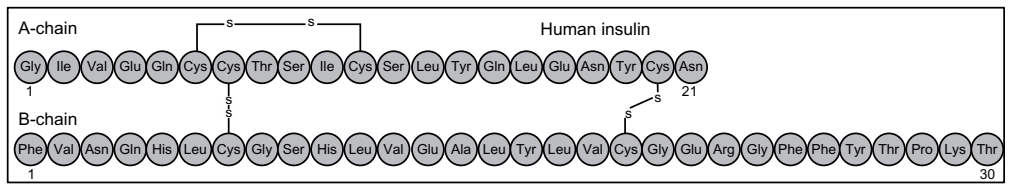

B

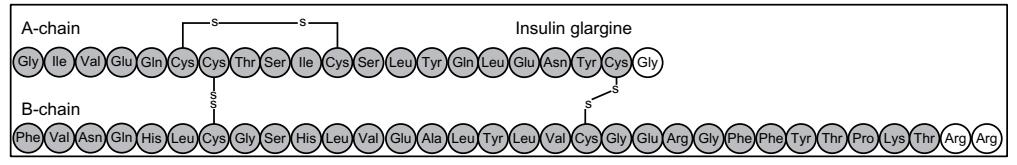

C

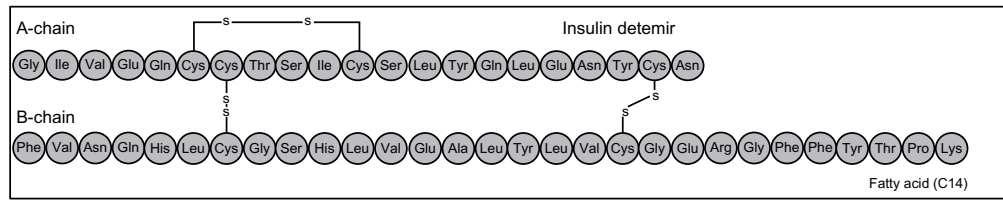

D

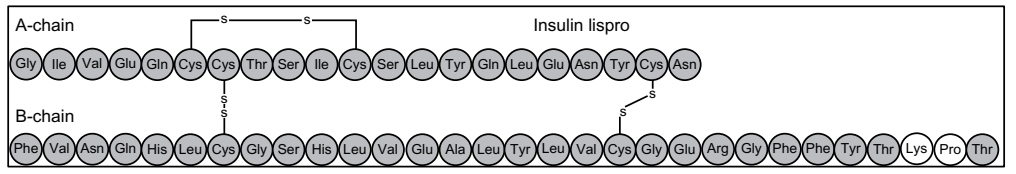

E

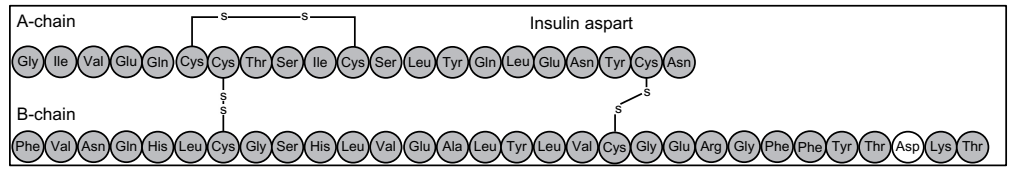

$\mathbf{F}$

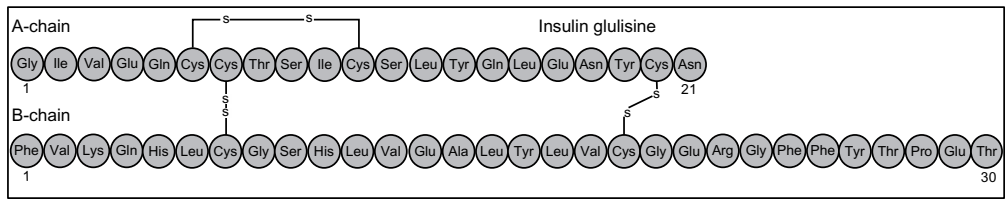

G

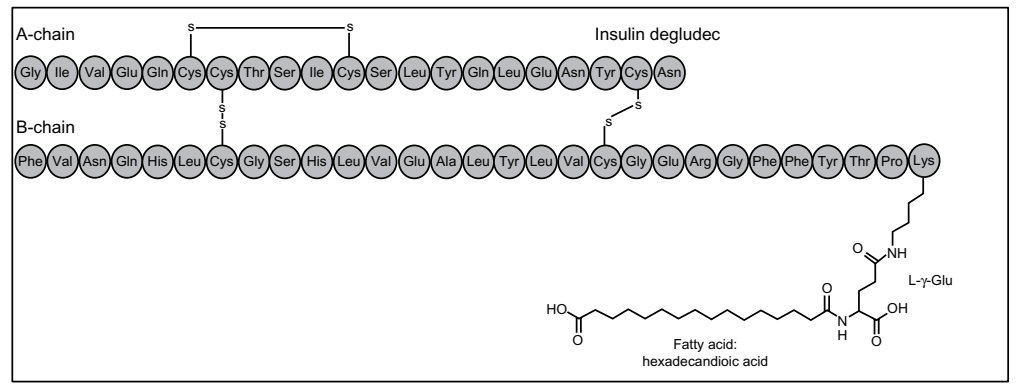

Figure 2 Structures of human insulin (A) and the long-acting basal insulin analogs insulin glargine (B), insulin detemir (C), insulin lispro (D), insulin aspart (E), insulin glulisine (F), and insulin degludec $(\mathbf{G})$.

there are no specific regulations for biosimilar development at the moment. ${ }^{22}$ In the EU, however, the European Medicines Agency's (EMA's) Guidance on Similar Medicinal Products Containing Recombinant Human Soluble Insulin ${ }^{23}$ and Guideline on Non-clinical and Clinical Development of Similar Biological Medicinal Products Containing Recombinant
Human Insulin and Insulin Analogues ${ }^{24}$ explain the general requirements for the demonstration of similarity between two product-class specific biological products in terms of safety and efficacy. Unlike the approval of generic medicines, biosimilar approval is based on similarity to the reference product (ie, biologically manufactured recombinant protein). 
Table I Insulin glargine copy manufacturers

\begin{tabular}{|c|c|c|}
\hline $\begin{array}{l}\text { Name of } \\
\text { manufacturer }\end{array}$ & Product & Marketed \\
\hline Gan and Lee & \multirow[t]{4}{*}{ Insulin glargine } & Basalin $^{\circledR}$ in People’s \\
\hline Pharmaceuticals, & & Republic of China (2005) \\
\hline Beijing, People's & & Bonglixan ${ }^{\circledR}$ in Mexico (2009) \\
\hline Republic of China & & Basalin $^{\circledR}$ in Thailand (201 I) \\
\hline Biocon, Bangalore, & \multirow[t]{4}{*}{ Insulin glargine } & Basalog $^{\circledR}$ in India (2009) \\
\hline \multirow[t]{3}{*}{ Karnataka, India } & & Basalog $^{\circledR}$ in Kenya (20I2) \\
\hline & & Vibrenta ${ }^{\circledR}$ in Bangladesh \\
\hline & & $(20 \mid 2)$ \\
\hline Wockhardt Ltd, & Insulin glargine & Glaritus $^{\circledR}$ in India (2009) \\
\hline \multicolumn{3}{|l|}{ Mumbai, India } \\
\hline Getz Pharma Pakistan, & Insulin glargine & Basagin $^{\circledR}$ in Pakistan (20।2) \\
\hline \multicolumn{3}{|l|}{ Karachi, Pakistan } \\
\hline ACI Ltd, Dhaka, & Insulin glargine & Glarine $^{\circledast}$ in Bangladesh \\
\hline Bangladesh & & $(20 \mid 2)$ \\
\hline Popular Pharma, & Insulin glargine & Insul Glargine ${ }^{\circledast}$ in \\
\hline Paramus, NJ, USA & & Bangladesh (20/2) \\
\hline
\end{tabular}

In the EU, regulators require proof of similarity with respect to quality, clinical efficacy, and safety, including adverse events and immunogenicity, which need to be tested in direct comparison to the reference product. ${ }^{25}$ In addition, a risk management plan as well as pharmacovigilance programs need to be presented in the submission dossier. ${ }^{24}$ As of April 2014, no biosimilar insulin products have received marketing authorization from the EMA. Marvel LifeSciences Ltd (Mumbai, India) submitted two series of applications to the EMA for various biosimilar insulins, but both were withdrawn by the company (discussed in detail in the "Between-product variability" section of this article).

As the EMA guideline forms the basis of many regulatory requirements used in many other countries, ${ }^{26}$ this review takes a European perspective of the regulations for biosimilar manufacture and approval.

\section{Key issues with biosimilar insulins: manufacturing process}

The manufacture of therapeutic biomolecules is a complex, proprietary, multistep process, and the specifics of the manufacturing process are generally fully known only by the manufacturer. ${ }^{27}$ Each step in the manufacturing process might influence the properties and quality attributes of the biomolecule, and therefore may introduce potential sources of

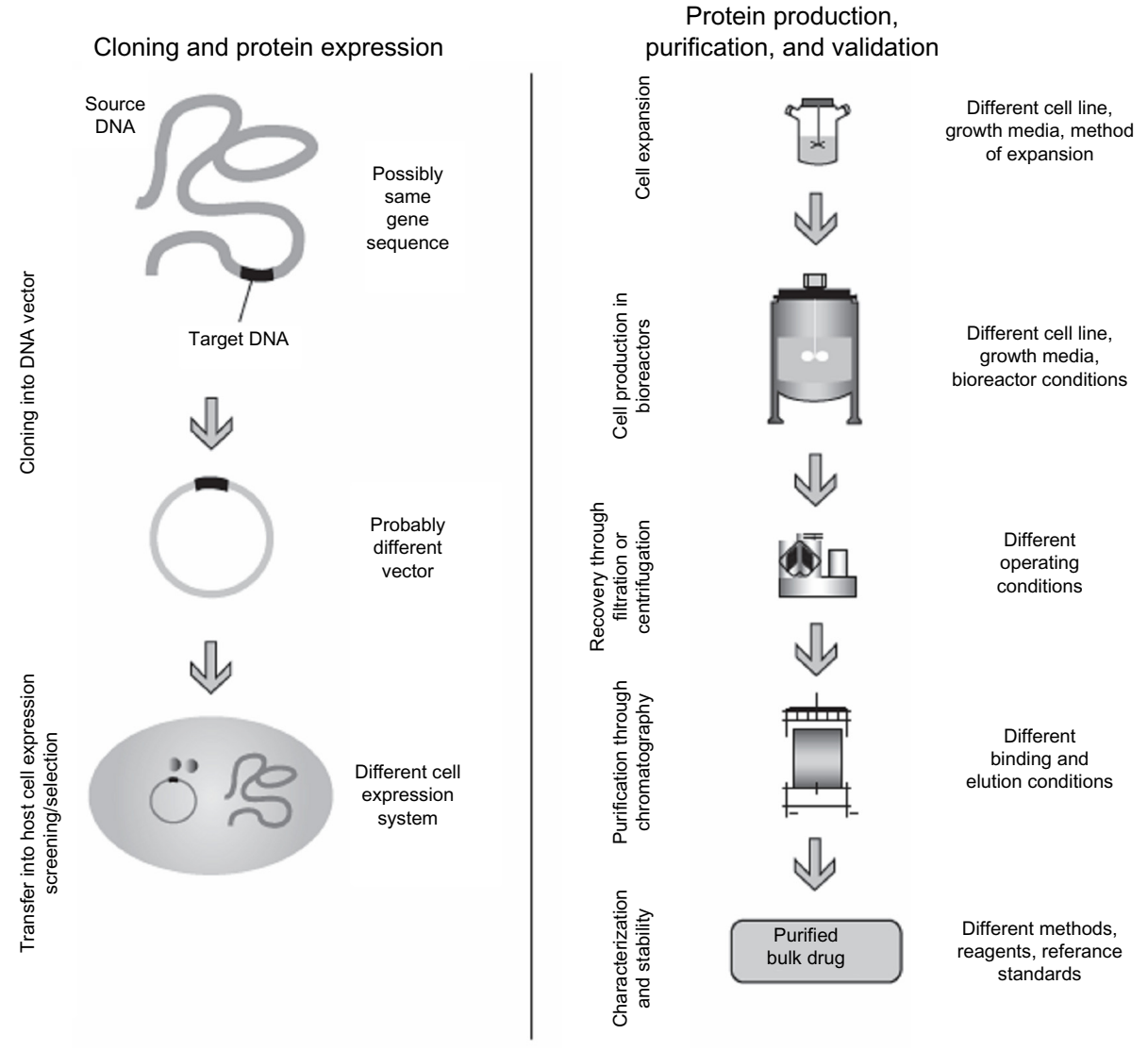

Figure 3 Sources of variation between manufacturers and batches of biosimilar products and reference originals.

Notes: Copyright @ 2008 Oxford University Press. Adapted by permission of Oxford University Press. Mellstedt H, Niederwieser D, Ludwig H. The challenge of biosimilars. Ann Oncol. 2008; I9(3):4I I-4I9. 
variability. Some of the main manufacturing steps associated with potential sources of variability are shown in Figure $3 .^{28}$ These include: selection of a suitable vector, influencing the process yield or degradation characteristics of soluble proteins; ${ }^{29}$ choice of appropriate production platform (ie, bacteria or yeast), which determines specific challenges and advantages for the overall process ${ }^{30,31}$ (the choice of host also has implications related to handling of the recombinant protein further down the production process) $;^{32}$ and protein production, purification, and isolation methods, developed according to the specific requirements of the desired process and product. For example, purification can involve a number of techniques, such as centrifugation, filtration, or chromatography, ${ }^{33}$ all of which can potentially lead to variations in the quality and properties of the final product.

Specifically for insulin and insulin analogs, a number of key steps are required in the development of the manufacturing processes. Production hosts, usually a bacterium (Escherichia coli) or yeast (Saccharomyces cerevisiae or Pichia pastoris), ${ }^{34}$ need to be selected. An overview of different host systems for insulin manufacture is shown in Table 2. This is followed by the development of appropriate downstream process parameters, such as isolation of the insulin precursor product and purification. In E. coli-based systems, recombinant proteins are produced in inclusion bodies, from which they need to be released and folded, with the formation of appropriate disulfide bonds via oxidation. Proteins produced in yeasts, however, are secreted into the culture medium already folded. ${ }^{31,35}$ Regardless of the expression system, the precursor protein

Table 2 Host systems for insulin manufacture

\begin{tabular}{|c|c|c|}
\hline Organism & Manufacturer & Insulin (brand) \\
\hline Escherichia coli & $\begin{array}{l}\text { Eli Lilly and Company, } \\
\text { Indianapolis, IN, USA }\end{array}$ & $\begin{array}{l}\text { Human insulin } \\
\text { (Huminsulin }^{\circledR} \text { ) }\end{array}$ \\
\hline E. coli & $\begin{array}{l}\text { Sanofi, Paris, } \\
\text { France }\end{array}$ & $\begin{array}{l}\text { Human insulin } \\
\left.\text { (Insuman }^{\circledR}\right)\end{array}$ \\
\hline E. coli & Eli Lilly and Company & $\begin{array}{l}\text { Insulin lispro (Humalog } \\
100^{\circledR} / \text { Liprolog }^{\circledR} \text { ) }\end{array}$ \\
\hline E. coli & Sanofi & $\begin{array}{l}\text { Insulin glargine } \\
\left(\text { Lantus }^{\circledR}\right)\end{array}$ \\
\hline E. coli & $\begin{array}{l}\text { Berlin-Chemie, Berlin, } \\
\text { Germany }\end{array}$ & $\begin{array}{l}\text { Human insulin } \\
\left(\text { Berlinsulin }{ }^{\circledR}\right)\end{array}$ \\
\hline E. coli & $\begin{array}{l}\text { Gan and Lee } \\
\text { Pharmaceuticals, Beijing, } \\
\text { People's Republic of China }\end{array}$ & $\begin{array}{l}\text { Insulin glargine copy } \\
\left(\text { Basalin }^{\circledR}\right)\end{array}$ \\
\hline Pichia pastoris & $\begin{array}{l}\text { Biocon, Bangalore, } \\
\text { Karnataka, India }\end{array}$ & $\begin{array}{l}\text { Insulin glargine copy } \\
\left(\text { Basalog }^{\circledR}\right)\end{array}$ \\
\hline $\begin{array}{l}\text { Saccharomyces } \\
\text { cerevisiae }\end{array}$ & $\begin{array}{l}\text { Novo Nordisk, Bagsvaerd, } \\
\text { Denmark }\end{array}$ & $\begin{array}{l}\text { Human insulin } \\
\text { (Insulin Actrapid }^{\circledR} \text { ) }\end{array}$ \\
\hline S. cerevisiae & Novo Nordisk & $\begin{array}{l}\text { Insulin aspart } \\
\left(\text { NovoRapid }^{\circledR}\right)\end{array}$ \\
\hline
\end{tabular}

has to be cleaved to remove pre- and postpeptides, using, for example, appropriate enzymes to produce a biologically active insulin molecule. The recombinant protein then needs further purification and concentration through crystallization and chromatography methods. ${ }^{36}$ This is followed by crystallization and/or lyophilization, as well as formulation into a product with clinical utility.

Different processes have been developed and established for the complex batch-based fermentation and purification of commercially available insulins and insulin analogs $;{ }^{26,36,37}$ an illustration of an E. coli-based process is shown in Figure $4 .{ }^{37}$ The process parameters applied at each step will leave an imprint on the product profile, resulting in a product whose quality attributes are contingent on the process that was used for manufacture, and with any variation in the methodology potentially affecting the clinical features of the biosimilar product. ${ }^{38}$ As discussed later, variability in biosimilar insulin products can theoretically affect clinical efficacy and safety. The method of production has given rise to the challenges in producing a biosimilar, ${ }^{39}$ and because identical reproduction of each step is unlikely between different manufacturers, biosimilar insulins may not be $100 \%$ identical to the reference originator protein. ${ }^{27}$ This has been reinforced by the Biosimilar Medicinal Products Working Party of the EMA. ${ }^{25}$ In registering a biosimilar product with the EMA or the US Food and Drug Administration, any differences from the marketed reference product have to be justified and evaluated, particularly with regard to any effect on product safety and efficacy. ${ }^{24,40-43}$

\section{Key issues with biosimilar insulins: variability}

The phenomenon of potential product variability needs to be addressed from two different perspectives. First, it is necessary to take into account potential differences between the biosimilar insulin product and the original product, and second, those potential differences between batches of biosimilar insulin. Thus, it involves potential variability between a given product and a biosimilar from a different manufacturer (ie, between-product variability) and variability between different batches of a single product from a single manufacturer (ie, within-product or batch-to-batch consistency). The sources of variability are complex, ${ }^{18,27,35}$ but as described earlier, they are similar for both between-product and within-product variability. The general principles discussed here apply for insulins, despite the fact that they are comparatively small biomolecules with a well-defined structure. 
Variability can be introduced at any stage in the manufacturing process, leading to changes in the biosimilar insulin molecule itself and/or in the folded final structures required for biological activity. ${ }^{29,35,44,45}$ In addition, the manufacture can introduce product- and process-related by-products derived from the expression vector and other impurities ${ }^{27}$ or lead to differential processing of the product (eg, oxidization or glycosylation). ${ }^{17}$ For example, a biosimilar insulin glargine manufactured in a yeast host, . pastoris, was shown to have three sugar molecules attached to it resulting from a different manufacturing process. ${ }^{46}$ When E. coli is used as the host, these by-products are not created. ${ }^{47}$ Variability in materials and conditions used in the manufacturing process (eg, cultivation conditions, cultivation-medium nutrient composition, and equipment design) or for storage can also introduce variability of quality attributes, and therefore affect the quality of the biosimilar insulin end-product. ${ }^{27,35}$

Although the root causes of variability lie within the manufacturing process, they may not always be easily identifiable. Applicants for a biosimilar product with identified differences to the reference product would be expected to evaluate the effect on safety and efficacy, using appropriately designed clinical and preclinical studies. Different production methods can potentially result in variable biosimilar products, with potential effects on clinical efficacy, safety, and, when trying to minimize variability, product cost, all of which may affect patients, physicians, and health care systems. ${ }^{18}$ Rigorous, controlled head-to-head clinical trials would be needed to confirm comparability of clinical profiles between a biosimilar and the originator product.

\section{Between-product variability}

As they are produced in multiple, complex manufacturing steps, biosimilar insulins are unlikely to be identical to the reference protein. It is the quality attributes of the originator product that determine the benchmarks against which the biosimilar is evaluated. These are used not only to establish similarity but also to justify acceptance criteria and specifications for the biosimilar. ${ }^{40-42}$

In the only formal submissions of biosimilar insulins for marketing approval in Europe with an officially released assessment, the manufacturer Marvel LifeSciences Ltd (Mumbai, India) withdrew the submissions for the intended biosimilar products Insulin Human Rapid Marvel, Insulin Human Long Marvel, and Insulin Human 30/70 Mix Marvel during the assessment process in response to serious concerns from the EMA. Several major deficiencies were identified that precluded a recommendation of marketing authorization, including incomplete information regarding the manufacturing processes
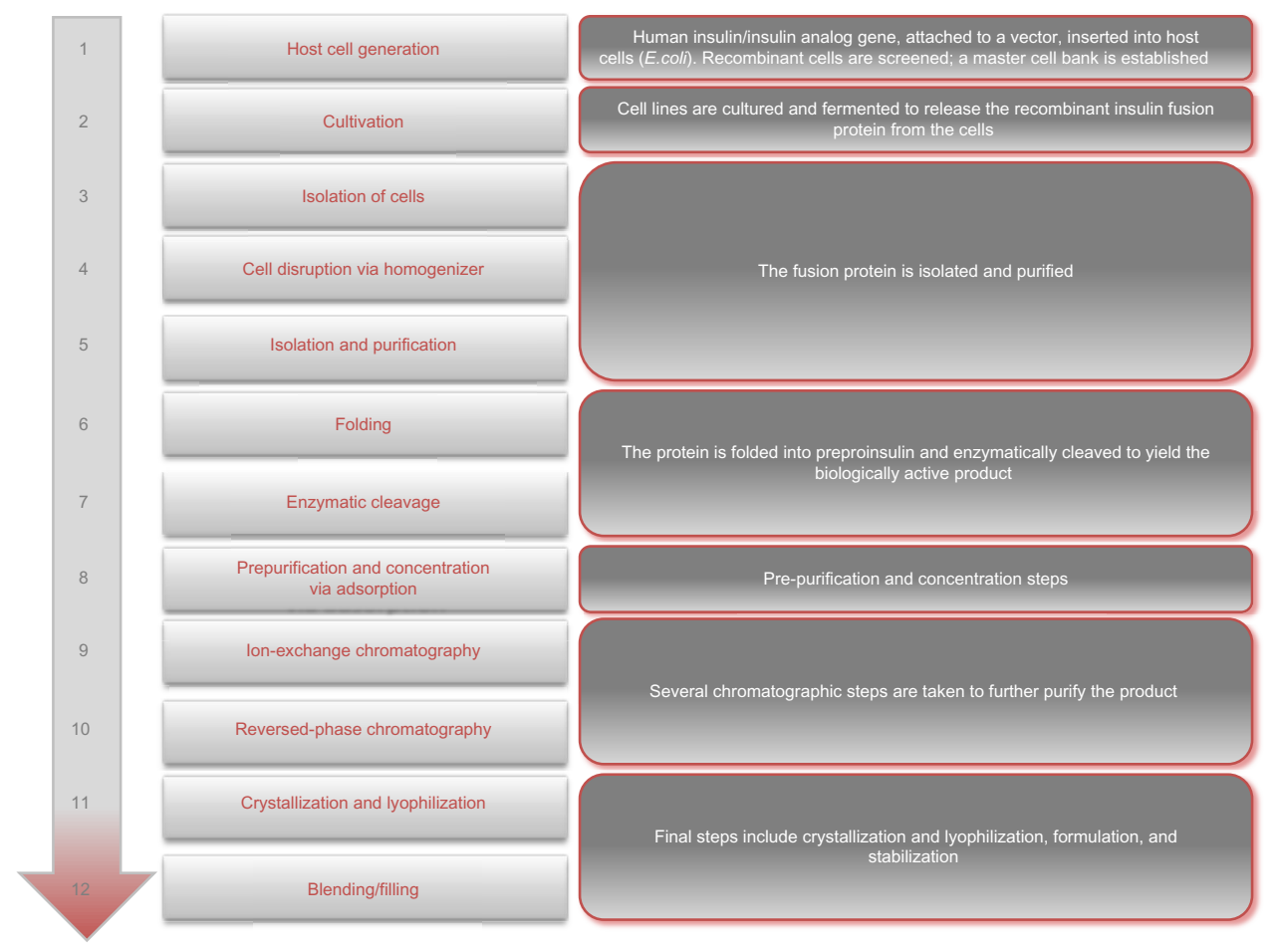

Figure 4 Manufacture of analog insulin using a bacterial host system. 
and quality validation aspects required to show biosimilarity between the biosimilar and the reference product, as well as deficiencies in nonclinical and clinical aspects. From the EMA's perspective, no comparability with the reference products had been demonstrated regarding the effect of lowering blood sugar levels. ${ }^{48-50}$ A subsequent submission for biosimilar human insulins (Solumarv, Isomarv medium, and Combimarv) by the same manufacturer was also withdrawn after the EMA found significant issues with the manufacture of the biosimilars, "a failure to conduct the studies in compliance with Good Clinical Practice," and a lack of good manufacturing practice certification of the production plants. ${ }^{51-53}$ Other major concerns of the EMA included clinical data deficiencies in the dossier and unjustified reprocessing of material or change of suppliers. In addition, information on the consistency of product quality was lacking. Furthermore, issues with pharmacological study reports were identified, and immunogenicity data were not presented. As a consequence of the missing good manufacturing practice certificates, a good clinical practice inspection of the contract research organization involved in the clinical trials for the biosimilar insulins was deemed necessary. The manufacturer withdrew the applications in 2012. The EMA's withdrawal assessment reports illustrate the rigorous pathway for the registration of biosimilars in Europe. ${ }^{51-54}$

Of note, the initial expense associated with ensuring strict adherence to good manufacturing practice guidelines and the quality control measures required to minimize differences in a biosimilar insulin for a manufacturer may offset the cost savings expected with biosimilar insulins. ${ }^{17,18}$

In addition to the manufacture per se, between-product variability can arise during storage in the postproduction period. The products' content of high-molecular-weight proteins (HMWPs) represents an example of this effect. Different levels of HMWPs have been found for insulin glargine copies: Lantus ${ }^{\circledR}$ (the reference product; Sanofi), Glaritus ${ }^{\circledR}$ (Wockhardt Ltd, Mumbai, India), and Basalin ${ }^{\circledR}$ (Gan and Lee Pharmaceuticals, Beijing, People's Republic of China).$^{35}$ The latter products are copies of the reference Lantus ${ }^{\circledR}$ that are marketed and registered in their respective countries of manufacture according to local regulatory legislation, without following a biosimilar approval approach. For each insulin glargine copy product, the level of HMWPs increases with sample age, as illustrated by batches with different ages at the time of analysis. In contrast, the levels observed in Lantus $^{\circledR}$ batches are considerably lower than those detected in Glaritus ${ }^{\circledR}$ and Basalin ${ }^{\circledR}$ for a given sample age (Figure 5A). When simulating actual product use by an appropriate in-use study for 28 days at $+25^{\circ} \mathrm{C}$, differences between Lantus ${ }^{\circledR}$ and the insulin glargine copies were even more prominent (Figure 5B; original data on file at Sanofi). The potential clinical effect of these differences is unknown.

The devices used for administration can also introduce potential variability, as compatibility of biosimilar products and existing devices is not guaranteed per se, and therefore has to be demonstrated. ${ }^{29}$ Insulins, for example, can be delivered by syringe/needle systems, disposable pens, cartridges, or reusable pens. Guidelines on the requirements of administration devices for liquid dosages are available. ${ }^{55,56}$ Pen administration devices were introduced to assist patient compliance through increased ease of use, and as patient awareness of insulin pens increases, it is important to identify those insulin pen characteristics that are most vital to optimizing patient acceptance and adherence. Injection force is a key parameter in the design of pen injection systems. ${ }^{57,58}$ Various disposable and reusable pens have recently been studied in this respect, and it has been reported that the administration devices that deliver insulin copies showed different performance characteristics compared with the originator devices. ${ }^{59-62}$ For example, Friedrichs et al most recently reported that injection forces with copy insulin pens available in India were significantly higher than those for original insulin devices, ${ }^{63}$ a physical difference that could lead to a potentially different patient experience.

\section{Within-product variability}

Within the life cycle of a registered biotechnology-derived product, manufacturers may consider adaptations of the manufacturing process to improve process performance or cost-effectiveness. According to European legislation, the comparability of pre- and postchange product has to be demonstrated as a possible surrogate for safety and efficacy. Confirmatory nonclinical or clinical studies might be considered appropriate. ${ }^{32}$ As a consequence, considerable variability can be observed in registered biotechnology-derived products on the implementation of postapproval process changes; for example, different isoforms or glycosylation patterns of recombinant biotherapeutic proteins. ${ }^{64}$ Furthermore, variability between different batches of a biomolecule from a single manufacturer also reflects the consistency of the manufacturing process and can be considered an indicator for the level of control of the manufacturing process. ${ }^{21}$

As shown in Figure 5, different within-product variability is observed for the different insulin glargine products, such as Lantus ${ }^{\circledR}$ and copy products, when comparing the HMWP levels of samples of similar age at the time of analysis (original data on file at Sanofi). 

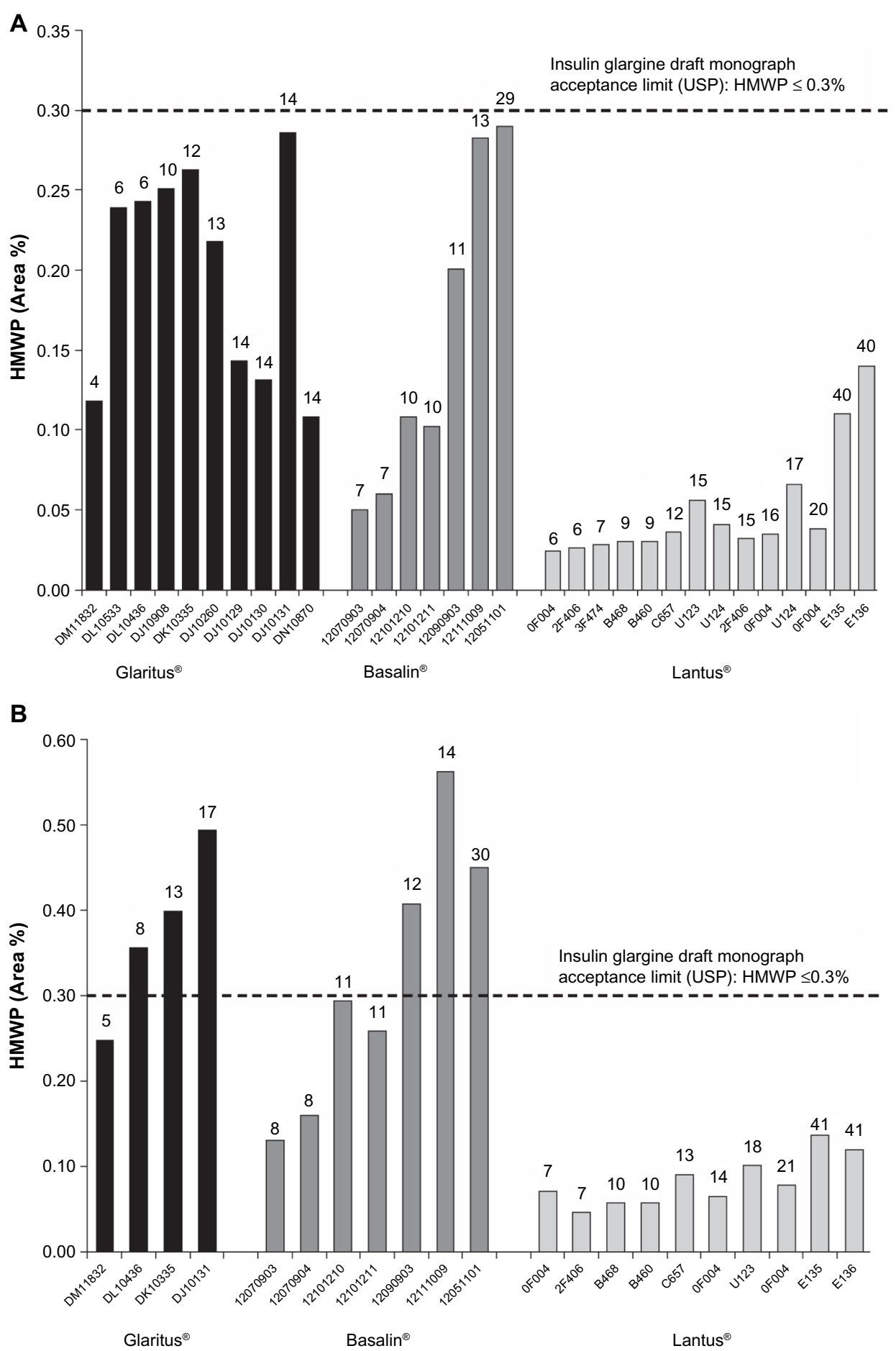

Figure 5 High-molecular-weight proteins (HMWP) in insulin glargine (original Lantus ${ }^{\circledR}$ and copy products) on direct testing (A) and after simulation of in-use period (28 days at $\left.+25^{\circ} \mathrm{C}\right)(\mathbf{B})$.

Notes: The sample age in months at the time of analysis is indicated above each column (original data on file at Sanofi). X axis represents different product batches. Glaritus ${ }^{\circledR}$, Wockhardt Ltd, Mumbai, India; Basalin ${ }^{\circledR}$, Gan and Lee Pharmaceuticals, Beijing, People’s Republic of China; Lantus ${ }^{\circledR}$, Sanofi, Paris, France.

Abbreviation: USP, United States Pharmacopeia.

Issues with production-related variability in the final biosimilar insulin product could affect clinical efficacy, with the potential of mild to severe hypoglycemia reactions or hyperglycemia-induced tissue damage, and may even have more serious patient safety consequences..$^{17,18,29,65}$

\section{Implications for patients, physicians, and health care systems}

Patient safety is the key issue to be evaluated not only during, but especially after the official approval process for biosimilar insulins. In this regard, patient safety includes the prevention 
of unexpected severe adverse events after switching from an originator substance to a biosimilar insulin and vice versa, or after first initiation of diabetes treatment with a biosimilar insulin. ${ }^{66}$ In the case of diabetes mellitus, various consequences of the manufacturing process, storage conditions, or administration devices could cause clinical sequelae, such as potential hypo- and hyperglycemic episodes.

Significant differences in PK and PD between a biosimilar insulin and its reference originator insulin may have relevant short-term effects on blood glucose control. Physicians and patients have the right to expect equivalent biological effects on a single dose level between a biosimilar insulin and the reference compound. This becomes most relevant when switching from one product to the biosimilar product without changing the insulin dose. The EMA has recognized this important issue, and therefore its Guideline on Non-clinical and Clinical Development of Similar Biological Medicinal Products Containing Recombinant Human Insulin and Insulin Analogues ${ }^{24}$ describes the requirement of a comparison of PK and PD properties between biosimilar and reference insulins (euglycemic glucose clamp study), such that at least one clinical single-dose crossover study is to be conducted to provide time-concentration profile data of the products after subcutaneous administration. Differences in the PK/PD profiles of Marvel's biosimilar recombinant insulin preparations Solumarv, Isomarv medium, and Combimarv were considered relevant by the EMA's Committee for Medicinal Products for Human Use after submission of the applications for marketing approval on December 5 , 2011. A list of questions was formulated by the committee to be answered by Marvel. While the Committee for Medicinal Products for Human Use was awaiting the company's response to the questions, the applicant decided to withdraw the three products on November 15, 2012, stating that "the decision to withdraw is in order to have sufficient time to repeat and submit bioequivalence [type-1 diabetes] PK/PD data on each clamp study in order to comply with the planned new insulin guideline." $51-53$

Variations in blood glucose levels might not solely be explained by differences in PK/PD profiles but may also be a result of inaccurate insulin delivery by the administration device. ${ }^{29}$ Accurate delivery of the prescribed dose of insulin is essential to guarantee maintenance of short- and longterm diabetes control. Biosimilar insulins will be marketed with their own administration devices, and switching a patient from an originator insulin to a biosimilar insulin will therefore include a change in administration devices. Acute hypo- or hyperglycemia may occur when the subcutaneously delivered amount of insulin is either significantly higher or lower than the dose prescribed and indicated on the administration device. Therefore, adequate quality control of administration devices and demonstration of equivalence with the originator device are of highest importance for patients and physicians. Important quality aspects include accuracy of the dose, as indicated by the device, as well as, very importantly, consistency of the delivered insulin dose when the same dose is given repeatedly. Among other points, the EMA recommends the evaluation of dosing devices in terms of normal capacity of the device, dosing accuracy and precision, interpretation and readability of the graduated scale, needle diameter in relation to the particle size of suspensions, and residual amounts of liquid in the device after administration. ${ }^{18}$

Another important aspect that may affect patient safety is the potential immunogenicity of therapeutic proteins, which may result in the formation of specific antidrug antibodies. ${ }^{67}$ In the case of insulin, anti-insulin antibodies, which most commonly have some neutralizing capacity, may negatively affect the blood glucose-lowering effect of the exogenous insulin and even cross-react with the endogenous protein. The occurrence of anti-insulin anti-bodies is not new to diabetology: they occurred early in the modern history of diabetes treatment, when the first insulins that became available for standard application were produced from porcine and bovine pancreas. Immunogenicity in this case occurred because of their nonhuman origin. Almost all patients treated with porcine or bovine insulin developed anti-insulin antibodies, which, because of their neutralizing nature, lowered the efficacy of insulin therapy and thus increased individual insulin dosing requirements. ${ }^{68,69}$

Despite more modern production processes, recombinant human insulins also induce the production of anti-insulin antibodies. However, the neutralizing effects of these antibodies appear to be less relevant in daily practice. Many product-related factors are considered to contribute to the immunogenicity of human therapeutic proteins, including primary structure, impurities, aggregates, and protein modifications such as PEGylation. ${ }^{70}$ It has been hypothesized that the reason for antibody formation by recombinant human insulins may be the high tendency of insulin to self-associate and aggregate into multimers. ${ }^{71}$ The occurrence of aggregates appears to be the most important pathophysiological factor driving the development of antidrug antibodies against therapeutic proteins. A possible cause of aggregation is interaction between the therapeutic protein and surfaces encountered during manufacture, fill and finish, storage, or administration. Proteins may either adsorb to particles 
on these surfaces or to particles shed from these surfaces. Interaction or adsorption of therapeutic proteins with various substances, including silicone rubber from delivery tubing, ${ }^{72}$ polyvinyl chloride from infusion bags, ${ }^{73}$ silicone oil from syringe lubricant, ${ }^{74}$ silica nanoparticles, ${ }^{75}$ tungsten leachates, ${ }^{76}$ and stainless steel microparticles, ${ }^{77,78}$ have been described. High endotoxin levels may also induce the production of antidrug antibodies. ${ }^{79}$ Interaction of protein with any of these particles can lead to direct adsorption of the protein to the particles or to surface-induced aggregation of free protein in solution.

Immunogenicity of a therapeutic protein can be categorized into two mechanisms, depending on the level of tolerance to the therapeutic protein. In the rare situation of low or nonexisting tolerance (eg, complete absence of an endogenous protein from birth), B-cells are activated by the classical T-cell-dependent pathway as a response to a foreign protein. In a situation of preexisting tolerance against the endogenous protein, as is the case with insulin-dependent type 2 diabetes mellitus patients, antibody generation requires breakage of the existing B-cell tolerance against the protein. Aggregates enhance the immunogenicity of a therapeutic human protein preferentially by breaking B-cell tolerance. This is explained by the fact that aggregates, by presenting multiple and repetitive epitopes of the therapeutic protein, mimic bacterial antigens. In this scenario, the B cells confuse the aggregated therapeutic agent with a bacterial antigen and consecutively produce specific antibodies. ${ }^{80}$ In addition to factors related to protein structure, production process, and storage and handling, many other patient-related factors, such as site of application (higher immunogenicity with subcutaneous versus intravenous application), individual and cumulative dose of the therapeutic protein, and frequency of application, also contribute to the occurrence of relevant antidrug antibody formation. ${ }^{81}$

A very instructive example of relevant production of antidrug antibodies against a therapeutic protein is the occurrence of pure red cell aplasia in dialysis patients treated with erythropoietin. Between 1999 and 2002, neutralizing anti-erythropoietin antibodies were identified in a cohort of European and Canadian dialysis patients who suffered from renal anemia unresponsive to even high doses of exogenous erythropoietin. ${ }^{82}$ In retrospect, the upsurge of pure red cell aplasia was related to a change in the formulation of the epoetin- $\alpha$ formulation used in the vast majority of cases, where human serum albumin had been replaced by polysorbate 80 in prefilled syringes. Although the definite cause of antibody-associated pure red cell aplasia is still a mystery today, most hypotheses are related to the occurrence of micelles or aggregates within the formulation, which potentially have been caused either by leachates from the rubber stopper of prefilled syringes or by the high concentrations of polysorbate 80 itself. Other hypotheses include the interruption of the cold chain or other, unknown ways of mishandling of the products that could lead to antibody formation. ${ }^{83}$

Anti-erythropoietin antibody formation was also reported quite recently in two patients treated with a biosimilar epoetin preparation during a phase 3 study conducted to gain approval for subcutaneous application. ${ }^{84,85}$ In these cases, aggregation as the most likely cause for immunogenicity was most likely induced by soluble tungsten, a metal that was an integral part of the production process of the barrels of prefilled syringes. Traces of tungsten were eventually detected in the formulation. Finally, findings of high levels of aggregates and substantial amounts of protein fragments, as well as high endotoxin levels, have recently been reported in some recombinant human erythropoietin copies marketed in Thailand. ${ }^{86,87}$ These examples clearly demonstrate that overall product quality appears to be the main determinant of protein immunogenicity. Small changes in the manufacturing process, in the end-product formulation, or in product handling may potentially affect clinical experience.

It is recognized that clinically evident and relevant antidrug antibody reactions are rare events and that the likelihood of detecting these reactions during the clinical studies required for EMA submission is low. For this reason, the EMA regulations require applicants for biosimilar insulins to present a pharmacovigilance program to ensure proper risk-assessment strategies and management through the recording of suspected adverse events and data collection from all interested parties: patients, physicians, pharmacists, nurses, other relevant health care professionals, regulatory authorities, pharmaceutical companies, and companies importing or distributing medicines. ${ }^{21,88,89}$ Monitoring of immunogenicity should be an integral part of pharmacovigilance activities. ${ }^{21,27,35,37,38,44,90}$ In addition, as there may be changes in a company's manufacturing process for a given drug, comprehensive risk-management programs should include regular evaluation of the manufacturing processes to ensure consistency, as well as processes that prescribing practitioners can easily use to accurately and consistently record and report any new safety signals. ${ }^{91,92}$ The EMA has developed "good pharmacovigilance practices" measures to facilitate the performance of pharmacovigilance in the EU. The measures cover medicines authorized centrally via the EMA well as medicines authorized at a country's national level. The modules covering major pharmacovigilance processes are expected to be released in the third quarter of 2014. Modules 
covering product-specific considerations are currently under development, with the chapter on biological medicinal products expected in the second quarter of $2014 .{ }^{93}$

All this implies that it is possible that a switch from originator insulin to biosimilar insulin could lead to unpredictable potential risks of clinical or safety consequences, such as hypo- or hyperglycemia and immunogenicity. Any change in prescription of therapeutic proteins should therefore be under the care of a physician and be clearly explained to the patient and considered carefully. This highlights a key difference in switching from originator insulin to biosimilar insulin compared with originator drug and chemically identical generic agents.

The European biosimilar approval process differs significantly from the generics approval process, but both processes have been designed with the same aim, which is to facilitate and regulate the production of biosimilars. The EMA has clearly stated that the issue of automatic substitution at the pharmacy level is beyond its current guidelines and should only occur after the instruction of a qualified health care professional. ${ }^{66}$ As stated earlier, because different manufacturers use different production cell lines and purification procedures, two therapeutic proteins, even if considered biosimilar, are not guaranteed to be identical and may differ in some regard that could potentially affect a product's immunogenic profile. A realistic complication of automatic substitution is that it may interfere with the ability to trace the source of immunogenicity or other safety-related problems.

With regard to regulations, the EMA leaves substitution decisions to national regulators. ${ }^{94}$ Automatic substitution is allowed in France for patients new to insulin; it is not allowed in Germany, Greece, Italy, Slovenia, Spain, Sweden, or the United Kingdom, and in Austria and the Czech Republic, prescription by brand name is mandatory and biosimilars are not allowed to be substituted. Other EU member states (eg, Denmark, Finland, Hungary, Norway, and Slovakia) publish official lists of products not to be substituted.

\section{Conclusion}

Biosimilar insulins have the potential to reduce medication costs, increase accessibility to insulin therapy for patients, and increase the range of options from which insulin treatments can be chosen by physicians in collaboration with patients. However, the complexities of the manufacturing process may lead to final product variability, despite the similarity of amino acid sequence between a biosimilar and its reference product. Differences between originator and biosimilar insulins can potentially lead to efficacy and safety/ immunogenicity consequences.

Specific regulatory standards for the approval of biosimilar insulins are well defined in Europe, but there is significant variability in the extent of clinical and quality evidence required for approval outside the EU. As payers, physicians, and patients have experience with and confidence in established insulin products for the treatment of diabetes, all these stakeholders in health care systems will need reassurance and clinical evidence of the long-term efficacy and safety of biosimilar insulins. Although health care system managers may implement incentives for an increased use of more cost-effective biosimilar products, it will take the collection of long-term evidence for biosimilar insulins to fully understand their clinical profile, as has been the case with the originator insulin products.

\section{Acknowledgments}

The contents of the article and the opinions expressed within are those of the authors, and it was the decision of the authors to submit the manuscript for publication. The authors received writing/editorial support in the preparation of this manuscript provided by Tessa Hartog, PhD, from Excerpta Medica, funded by Sanofi US, Inc.

\section{Author contributions}

Both authors contributed to the writing of this manuscript, including critical review and editing of each draft, and to approval of the submitted version. Both authors contributed toward data acquisition and interpretation, and agree to be accountable for all aspects of the work.

\section{Disclosure}

Martin K Kuhlmann has received speaker's honoraria from Sanofi and is a member of a Sanofi global advisory board on insulin biosimilars. Andrea Schmidt is an employee of Sanofi, Frankfurt, Germany. The authors report no other conflicts of interest in this work.

\section{References}

1. International Diabetes Federation. IDF Diabetes Atlas. 6th ed. Brussels: International Diabetes Federation; 2013. Available from: http://www.idf. org/diabetesatlas. Accessed April 27, 2014.

2. Centers for Disease Control and Prevention. National Diabetes Fact Sheet: National Estimates and General Information on Diabetes and Prediabetes in the United States, 2011. Atlanta: US Department of Health and Human Services, Centers for Disease Control and Prevention; 2011. Available from: http://www.cdc.gov/diabetes/pubs/pdf/ndfs_2011.pdf. Accessed April 27, 2014.

3. Jabbour S. Primary care physicians and insulin initiation: multiple barriers, lack of knowledge or both? Int J Clin Pract. 2008;62(6):845-847. 
4. Inzucchi SE, Bergenstal RM, Buse JB, et al; American Diabetes Association (ADA); European Association for the Study of Diabetes (EASD). Management of hyperglycemia in type 2 diabetes: a patientcentered approach: position statement of the American Diabetes Association (ADA) and the European Association for the Study of Diabetes (EASD). Diabetes Care. 2012;35(6):1364-1379.

5. Yki-Järvinen H, Dressler A, Ziemen M; HOE 901/3002 Study Group. Less nocturnal hypoglycemia and better post-dinner glucose control with bedtime insulin glargine compared with bedtime NPH insulin during insulin combination therapy in type 2 diabetes. HOE 901/3002 Study Group. Diabetes Care. 2000;23(8):1130-1136.

6. Rosenstock J, Schwartz SL, Clark CM Jr, Park GD, Donley DW, Edwards MB. Basal insulin therapy in type 2 diabetes: 28-week comparison of insulin glargine (HOE 901) and NPH insulin. Diabetes Care. 2001;24(4):631-636.

7. Homko C, Deluzio A, Jimenez C, Kolaczynski JW, Boden G. Comparison of insulin aspart and lispro: pharmacokinetic and metabolic effects. Diabetes Care. 2003;26(7):2027-2031.

8. Riddle MC, Rosenstock J, Gerich J; Insulin Glargine 4002 Study Investigators. The treat-to-target trial: randomized addition of glargine or human NPH insulin to oral therapy of type 2 diabetic patients. Diabetes Care. 2003;26(11):3080-3086.

9. Raslová K, Bogoev M, Raz I, Leth G, Gall MA, Hâncu N. Insulin detemir and insulin aspart: a promising basal-bolus regimen for type 2 diabetes. Diabetes Res Clin Pract. 2004;66(2):193-201. Erratum in: Diabetes Res Clin Pract. 2006;72:112.

10. Becker RH, Frick AD, Burger F, Scholtz H, Potgieter JH. A comparison of the steady-state pharmacokinetics and pharmacodynamics of a novel rapid-acting insulin analog, insulin glulisine, and regular human insulin in healthy volunteers using the euglycemic clamp technique. Exp Clin Endocrinol Diabetes. 2005;113(5):292-297.

11. Hermansen K, Davies M, Derezinski T, Martinez Ravn G, Clauson P, Home P; Levemir Treat-to-Target Study Group. A 26-week, randomized, parallel, treat-to-target trial comparing insulin detemir with NPH insulin as add-on therapy to oral glucose-lowering drugs in insulin-naive people with type 2 diabetes. Diabetes Care. 2006;29(6):1269-1274.

12. Hilgenfeld R, Seipke G, Berchtold H, Owens DR. The evolution of insulin glargine and its continuing contribution to diabetes care. Drugs. 2014;74(8):911-927.

13. Lantus ${ }^{\circledR}$ (insulin glargine [rDNA origin] injection) [prescribing information]. Bridgewater, NJ: sanofi-aventis; 2007.

14. Levemir ${ }^{\circledR}$ (insulin detemir [rDNA origin] injection) [prescribing information]. Princeton, NJ: Novo Nordisk; 2007.

15. Vázquez-Carrera M, Silvestre JS. Insulin analogues in the management of diabetes. Methods Find Exp Clin Pharmacol. 2004;26(6):445-461.

16. Nasrallah SN, Reynolds LR. Insulin degludec, the new generation basal insulin or just another basal insulin? Clin Med Insights Endocrinol Diabetes. 2012;5:31-37.

17. Rotenstein LS, Ran N, Shivers JP, Yarchoan M, Close KL. Opportunities and challenges for biosimilars: What's on the horizon in the global insulin market? Clin Diabetes. 2012;30(4):138-150.

18. Heinemann L, Hompesch M. Biosimilar insulins: how similar is similar? J Diabetes Sci Technol. 2011;5(3):741-754.

19. Biocon Enhances Partnership with Mylan Through Strategic Collaboration for Insulin Products. Bangalore, India: Biocon; 2013. Available from: http://www.biocon.com/docs/PR_Biocon_ Mylan_14022013.pdf. Accessed June 11, 2014.

20. Wockhardt. Immunogenicity study of Wockhardt's insulin lispro/lispro mix basal bolus regimen in type 1 diabetics. Available from: http:// www.clinicaltrials.gov/ct2/show/NCT01398670. NLM identifier: NCT01398670. Accessed June 11, 2014.

21. World Health Organization. Guidelines on Evaluation of Similar Biotherapeutic Products (SBPS). Geneva: World Health Organization; 2009. Available from: http://www.who.int/biologicals/ areas/biological_therapeutics/BIOTHERAPEUTICS_FOR_ WEB_22APRIL2010.pdf?ua=1. Accessed April 27, 2014.
22. Reddy S, Balamuralidhara V, Pramod KumarTM, Reddy S. Regulatory strategies for biosimilars in regulated and emerging markets. Pharma Times. 2013;45(1):11-14.

23. European Medicines Agency. Guidance on Similar Medicinal Products Containing Recombinant Human Soluble Insulin. EMEA/CHMP/ BMWP/32775/2005. London: European Medicines Agency; 2006. Available from: http://www.ema.europa.eu/docs/en_GB/document_ library/Scientific_guideline/2009/09/WC500003957.pdf. Accessed April 27, 2014.

24. European Medicines Agency. Guideline on Non-Clinical and Clinical Development of Similar Biological Medicinal Products Containing Recombinant Human Insulin and Insulin Analogues. EMA/134217/2012 (EMEA/CHMP/BMWP/32775/2005_Rev. 1). London: European Medicines Agency; 2012. Available from: http://www.ema.europa. eu/docs/en_GB/document_library/Scientific_guideline/2012/12/ WC500136392.pdf. Accessed April 27, 2014.

25. Weise M, Bielsky MC, De Smet K, et al. Biosimilars-why terminology matters. Nat Biotechnol. 2011;29(8):690-693.

26. Amgen. Biologics and Biosimilars: An Overview. Available from: http:// www.amgen.com/pdfs/misc/Biologics_and_Biosimilars_Overview.pdf. Accessed August 11, 2014.

27. Heinemann L. Biosimilar insulins. Expert Opin Biol Ther. 2012;12(8): 1009-1016.

28. Mellstedt H, Niederwieser D, Ludwig H. The challenge of biosimilars. Ann Oncol. 2008;19(3):411-419.

29. Krämer I, Sauer T. The new world of biosimilars: what diabetologists need to know about biosimilar insulins. Br J Diabetes Vasc Dis. 2010;10(4):163-171.

30. Schmidt FR. Recombinant expression systems in the pharmaceutical industry. Appl Microbiol Biotechnol. 2004;65(4):363-372.

31. Dingermann T. Recombinant therapeutic proteins: production platforms and challenges. Biotechnol J. 2008;3(1):90-97.

32. European Medicines Agency. Note for Guidance on Biotechnological/ Biological Products Subject to Changes in their Manufacturing Process. CPMP/ICH/5721/03. London: European Medicines Agency; 2005. Available from: http://www.ema.europa.eu/docs/en_GB/document library/Scientific_guideline/2009/09/WC500002805.pdf. Accessed April 27, 2014.

33. Kalyanpur M. Downstream processing in the biotechnology industry. Mol Biotechnol. 2002;22(1):87-98.

34. Zündorf I, Dingermann T. Vom Rinder-, Schweine-, Pferde-Insulin zum Humaninsulin: Die biotechnische und gentechnische Insulin-Herstellung: Bereitstellung ausreichender Mengen von Humaninsulin. [From cattle, swine, and horse insulin to human insulin: the biotechnology and genetic technology of insulin production]. Pharm Unserer Zeit. 2001;30(1):27-32. German.

35. Owens DR, Landgraf W, Schmidt A, Bretzel RG, Kuhlmann MK. The emergence of biosimilar insulin preparations - a cause for concern? Diabetes Technol Ther. 2012;14(11):989-996.

36. Walsh G. Therapeutic insulins and their large-scale manufacture. Appl Microbiol Biotechnol. 2005;67(2):151-159.

37. Kuhlmann M, Marre M. Lessons learned from biosimilar epoetins and insulins. Br J Diabetes Vasc Dis. 2010;10(2):90-97.

38. Kuhlmann M, Covic A. The protein science of biosimilars. Nephrol Dial Transplant. 2006;21(Suppl 5):v4-v8.

39. Gough S. Biosimilar insulins: opportunities and challenges. Practical Diabetes. 2013;30(4):146a-147a.

40. US Food and Drug Administration. Guidance for Industry: Scientific Considerations in Demonstrating Biosimilarity to a Reference Product. Rockville, MD: US Food and Drug Administration; 2012. Available from: http://www.fda.gov/downloads/Drugs/GuidanceComplianceRegulatory Information/Guidances/UCM291128.pdf. Accessed April 27, 2014.

41. US Food and Drug Administration. Guidance for Industry: Quality Considerations in Demonstrating Biosimilarity to a Reference Protein Product. Rockville, MD: US Food and Drug Administration; 2012. Available from: http://www.fda.gov/downloads/Drugs/Guidance ComplianceRegulatoryInformation/Guidances/UCM291134.pdf. Accessed April 27, 2014. 
42. US Food and Drug Administration. Guidance for Industry: Biosimilars: Questions and Answers Regarding Implementation of the Biologics Price Competition and Innovation Act of 2009. Rockville, MD: US Food and Drug Administration; 2012. Available from: http://www.fda gov/downloads/Drugs/GuidanceComplianceRegulatoryInformation/ Guidances/UCM273001.pdf. Accessed April 27, 2014.

43. European Medicines Agency. Update of Questions and Answers on Biosimilar Medicines. London: European Medicines Agency; 2012. Available from: http://www.ema.europa.eu/docs/en_GB/document library/Presentation/2012/05/WC500127917.pdf. Accessed April 27, 2014.

44. Kozlowski S, Woodcock J, Midthun K, Sherman RB. Developing the nation's biosimilars program. $N$ Engl J Med. 2011;365(5):385-388.

45. Dranitsaris G, Amir E, Dorward K. Biosimilars of biological drug therapies: regulatory, clinical and commercial considerations. Drugs. 2011;71(12):1527-1536

46. Kannan V, Narayanaswamy P, Gadamsetty D, Hazra P, Khedkar A, Iyer H. A tandem mass spectrometric approach to the identification of O-glycosylated glargine glycoforms in active pharmaceutical ingredient expressed in Pichia pastoris. Rapid Commun Mass Spectrom. 2009;23(7):1035-1042.

47. Demain AL, Vaishnav P. Production of recombinant proteins by microbes and higher organisms. Biotechnol Adv. 2009;27(3):297-306.

48. European Medicines Agency. Withdrawal Assessment Report for Insulin Human Long Marvel. EMEA/CHMP/70349/2008. London: European Medicines Agency; 2008. Available from: http://www.ema. europa.eu/docs/en_GB/document_library/Application_withdrawal_ assessment_report/2010/01/WC500067170.pdf. Accessed April 27, 2014.

49. European Medicines Agency. Withdrawal Assessment Report for Insulin Human Rapid Marvel. EMEA/CHMP/317778/2007. London: European Medicines Agency; 2008. Available from: http://www.ema europa.eu/docs/en_GB/document_library/Application_withdrawal_ assessment_report/2010/01/WC500067086.pdf. Accessed August 11, 2014.

50. European Medicines Agency. Withdrawal Assessment Report for Insulin Human 30/70 Mix Marvel. EMEA/CHMP/70179/2008. London: European Medicines Agency; 2008. Available from: http://www.ema.europa.eu/ docs/en_GB/document_library/Application_withdrawal_assessment_ report/2010/01/WC500067169.pdf. Accessed April 27, 2014.

51. European Medicines Agency. Withdrawal Assessment Report: Combimarv. EMA/CHMP/780907/2012. London: European Medicines Agency; 2013. Available from: http://www.ema.europa.eu/docs/en_GB/ document_library/Application_withdrawal_assessment_report/2013/02/ WC500138884.pdf. Accessed April 27, 2014.

52. European Medicines Agency. Withdrawal Assessment Report: Isomarv Medium. EMA/CHMP/780915/2012. London: European Medicines Agency; 2013. Available from: http://www.ema.europa.eu/docs/ en_GB/document_library/Application_withdrawal_assessment_ report/2013/02/WC500138885.pdf. Accessed April 27, 2014.

53. European Medicines Agency. Withdrawal Assessment Report: Solumarv. EMA/CHMP/780927/2012. London: European Medicines Agency; 2013. Available from: http://www.ema.europa.eu/docs/ en_GB/document_library/Application_withdrawal_assessment_ report/2013/02/WC500138886.pdf. Accessed April 27, 2014.

54. European Medicines Agency. Guideline on Similar Biological Medicinal Products Containing Biotechnology-Derived Proteins as Active Substance: Non-Clinical and Clinical Issues. EMEA/CHMP/ BMWP/42832/2005 Rev. 1. London: European Medicines Agency; 2013. Available from: http://www.ema.europa.eu/docs/en_GB document_library/Scientific_guideline/2013/06/WC500144124.pdf. Accessed April 27, 2014.

55. European Medicines Agency. Guideline on the Suitability of the Graduation of Delivery Devices for Liquid Dosage Forms. EMEA/ CHMP/QWP/178621/2004. London: European Medicines Agency; 2005. Available from: http://www.ema.europa.eu/docs/en_GB/ document_library/Scientific_guideline/2009/09/WC500003660.pdf. Accessed April 27, 2014
56. International Organization for Standardization. ISO 11608-1:2000: Pen-Injectors for Medical Use - Part 1: Pen Injectors - Requirements and Test Methods. Available from: http://www.iso.org/iso/catalogue_ detail.htm?csnumber=19545. Accessed April 27, 2014.

57. Bode A. Development of the SoloSTAR insulin pen device: design verification and validation. Expert Opin Drug Deliv. 2009;6(1): $103-112$.

58. Perfetti R. Reusable and disposable insulin pens for the treatment of diabetes: understanding the global differences in user preference and an evaluation of inpatient insulin pen use. Diabetes Technol Ther. 2010;12(Suppl 1):S79-S85.

59. van der Burg T. Injection force of SoloSTAR ${ }^{\circledR}$ compared with other disposable insulin pen devices at constant volume flow rates. J Diabetes Sci Technol. 2011;5(1):150-155.

60. Krzywon M, van der Burg T, Fuhr U, Schubert-Zsilavecz M,Abdel-Tawab M. Study on the dosing accuracy of commonly used disposable insulin pens. Diabetes Technol Ther. 2012;14(9): 804-809.

61. Friedrichs A, Bohnet J, Korger V, Adler S, Schubert-Zsilavecz M, Abdel-Tawab M. Dose accuracy and injection force of different insulin glargine pens. J Diabetes Sci Technol. 2013;7(5):1346-1353.

62. Tschiedel B, Almeida O, Redfearn J, Flacke F. Initial experience and evaluation of reusable insulin pen devices among patients with diabetes in emerging countries: perceptions and ratings of AllStar ${ }^{\circledR}$, NovoPen $4^{\circledR}$, HumaPen Ergo II $^{\circledR}$, HumaPen Luxura ${ }^{\circledR}$, Xuilin Pen ${ }^{\circledR}$, and INSUPen ${ }^{\circledR}$. Diabetes Res Clin Pr. 2014;103 (Supp1 1):S60-S61.

63. Friedrichs A, Korger V, Adler S. Injection force of reusable insulin pens available in India: AllStar, Glaritus Pen Royale, HumaPen Ergo, InsuPen, NovoPen 3, NovoPen 4 [Abstract P-246]. Poster presented at: 7th International Conference on Advanced Technologies and Treatments for Diabetes; February 5-8, 2014; Vienna, Austria. Diabetes Technol Ther. 2014;16(Suppl 1):A-96.

64. Schiestl M, Stangler T, Torella C, Cepeljnik T, Toll H, Grau R. Acceptable changes in quality attributes of glycosylated biopharmaceuticals. Nat Biotechnol. 2011;29(4):310-312.

65. Home P. Biosimilar insulins. Diabetes Voice. 2011;56(2):40-43.

66. European Medicines Agency. Overview of Comments Received on 'Guideline on Similar Biological Medicinal Products Containing Monoclonal Antibodies.' EMA/CHMP/BMWP/403543/2010. London: European Medicines Agency; 2012. Available from: http:// www.ema.europa.eu/docs/en_GB/document_library/Other/2012/06/ WC500128687.pdf. Accessed June 11, 2014.

67. US Food and Drug Administration. Guidance for Industry: Immunogenicity Assessment for Therapeutic Protein Products. Rockville, MD: US Food and Drug Administration; 2013. Available from: http://www.fda.gov/downloads/Drugs/GuidanceCompliance RegulatoryInformation/Guidances/UCM338856.pdf. Accessed June 11, 2014.

68. Berson SA, Yalow RS, Bauman A, Rothschild MA, Newerly K. Insulin- ${ }^{131}$ metabolism in human subjects: demonstration of insulin binding globulin in the circulation of insulin treated subjects. $J$ Clin Invest. 1956;35(2):170-190.

69. Asplin CM, Hartog M, Goldie DJ. Change of insulin dosage, circulating free and bound insulin and insulin antibodies on transferring diabetics from conventional to highly purified porcine insulin. Diabetologia. 1978;14(2):99-105.

70. Schellekens H. Bioequivalence and the immunogenicity of biopharmaceuticals. Nat Rev Drug Discov. 2002;1(6):457-462.

71. Fineberg SE, Kawabata TT, Finco-Kent D, Fountaine RJ, Finch GL, Krasner AS. Immunological responses to exogenous insulin. Endocr Rev. 2007;28(6):625-652.

72. Tzannis ST, Hrushesky WJM, Wood PA, Przybycien TM. Adsorption of a formulated protein on a drug delivery device surface. $J$ Colloid Interface Sci. 1997;189(2):216-228.

73. McLeod AG, Walker IR, Zheng S, Hayward CP. Loss of factor VIII activity during storage in PVC containers due to adsorption. Haemophilia. 2000;6(2):89-92. 
74. Jones LS, Kaufmann A, Middaugh CR. Silicone oil induced aggregation of proteins. J Pharm Sci. 2005;94(4):918-927.

75. Chi EY, Weickmann J, Carpenter JF, Manning MC, Randolph TW. Heterogeneous nucleation-controlled particulate formation of recombinant human platelet-activating factor acetylhydrolase in pharmaceutical formulation. J Pharm Sci. 2005;94(2):256-274.

76. Bee JS, Nelson SA, Freund E, Carpenter JF, Randolph TW. Precipitation of a monoclonal antibody by soluble tungsten. J Pharm Sci. 2009;98(9):3290-3301.

77. Bee JS, Davis M, Freund E, Carpenter JF, Randolph TW. Aggregation of a monoclonal antibody induced by adsorption to stainless steel. Biotechnol Bioeng. 2010;105(1):121-129.

78. Van Beers MMC, Gilli F, Schellekens H, Randolph TW, Jiskoot W. Immunogenicity of recombinant human interferon beta interacting with particles of glass, metal, and polystyrene. J Pharm Sci. 2012;101(1): 187-199.

79. Schellekens H. Relationship between biopharmaceutical immunogenicity of epoetin alfa and pure red cell aplasia. Curr Med Res Opin. 2003;19(5):433-434.

80. Schellekens H. The immunogenicity of therapeutic proteins. Discov Med. 2010;9(49):560-564.

81. Sauerborn M, Brinks V, Jiskoot W, Schellekens H. Immunological mechanism underlying the immune response to recombinant human protein therapeutics. Trends Pharmacol Sci. 2010;31(2):53-59.

82. Casadevall N, Nataf J, Viron B, et al. Pure red-cell aplasia and antierythropoietin antibodies in patients treated with recombinant erythropoietin. N Engl J Med. 2002;346(7):469-475.

83. Schellekens H, Jiskoot W. Erythropoietin-associated PRCA: still an unsolved mystery. J Immunotoxicol. 2006;3(3):123-130.

84. Seidl A, Hainzl O, Richter M, et al. Tungsten-induced denaturation and aggregation of epoetin alfa during primary packaging as a cause of immunogenicity. Pharm Res. 2012;29(6):1454-1467.
85. Haag-Weber M, Eckardt KU, Hörl WH, Roger SD, Vetter A, Roth K. Safety, immunogenicity and efficacy of subcutaneous biosimilar epoetin- $\alpha$ (HX575) in non-dialysis patients with renal anemia: a multi-center, randomized, double-blind study. Clin Nephrol. 2012;77(1):8-17.

86. Praditpornsilpa K, Tiranathanagul K, Kupatawintu P, et al. Biosimilar recombinant human erythropoietin induces the production of neutralizing antibodies. Kidney Int. 2011;80(1):88-92.

87. Halim LA, Brinks V, Jiskoot W, et al. How bio-questionable are the different recombinant human erythropoietin copy products in Thailand? Pharm Res. [Epub November 21, 2013 ahead of print.] doi:http://dx.doi.org/10.1007/s11095-013-1243-9.

88. US Food and Drug Administration. Guidance for Industry: E2E Pharmacovigilance Planning. Rockville, MD: US Food and Drug Administration; 2005. Available from: http://www.fda.gov/downloads/drugs/guidancecomplianceregulatoryinformation/guidances/ ucm073107.pdf. Accessed April 27, 2014.

89. European Commission. The EU Pharmacovigilance System. Brussels: European Commission; 2014. Available from: http://ec.europa.eu/health/ human-use/pharmacovigilance/index_en.htm. Accessed April 27, 2014.

90. Joshi SR. Biosimilar peptides: need for pharmacovigilance. J Assoc Physicians India. 2011;59(Suppl):44-47.

91. Locatelli F, Roger S. Comparative testing and pharmacovigilance of biosimilars. Nephrol Dial Transplant. 2006;21(Suppl 5):v13-v16.

92. Casadevall N, Edwards IR, Felix T, et al. Pharmacovigilance and biosimilars: considerations, needs and challenges. Expert Opin Biol Ther. 2013;13(7):1039-1047.

93. European Medicines Agency. Good Pharmacovigilance Practices. Available from: http://www.ema.europa.eu/ema/index. jsp?curl=pages/regulation/document_listing/document_listing_000345. jsp\&mid=WC0b01ac058058f32c. Accessed June 11, 2014.

94. McCamish M, Woollett G. Worldwide experience with biosimilar development. MAbs. 2011;3(2):209-217.
Biosimilars

\section{Publish your work in this journal}

Biosimilars is an international, peer-reviewed, open access journal focusing on the manufacture, development and medicinal use of biopharmaceutical compounds considered similar to an innovator agent. Specific topics covered in the journal include: Regulatory issues and pathways; manufacturing processes; chemical composition and

\footnotetext{
Submit your manuscript here: http://www.dovepress.com/biosimilars-journal
}

\section{Dovepress}

structure; quality and purity; patent issues; bioequivalence and interchangeability; clinical efficacy data; patient perspectives. The manuscript management system is completely online and includes a very quick and fair peer-review system. Visit http://www.dovepress.com/ testimonials.php to read real quotes from published authors. 